\title{
À GUISA DE CONCLUSÃO: O HABITUS DE PESQUISADORES E PESQUISADORAS INSERIDOS NO MUNDO
}

\section{Amon Narciso de Barros ${ }^{1}$}

As discussões trazidas pelos textos anteriores e o debate transcrito acima nos levam a reconhecer a importância de uma dimensão por vezes esquecida no cotidiano da pesquisa: o conjunto de disposições inscritas no pesquisador, ao qual ele recorre, ainda que não consiga formalizá-lo. Nesse sentido, destaque inicial foi dado às estratégias e táticas que são empregadas no desenvolvimento da pesquisa e que deveriam ser alvo de reflexão, especialmente por parte daqueles que formam novos pesquisadores.

Imediatamente somos chamados a refletir sobre o papel do método nesse silenciamento das múltiplas dimensões que compõem a pesquisa. $\mathrm{O}$ método hipertrofiado foi apontado como instrumento para estabelecer uma suposta separação entre o eu que pesquisa e o outro, o objeto pesquisado. Dessa forma, desassocia-se o pesquisador de seus efeitos e de suas responsabilidades políticas. Também se abre espaço para que o pesquisador deixe de ver a si mesmo como fruto de um dado contexto sócio-histórico e como agente impactado por essas forças incontornáveis. O método, então, permitiria um alheamento confortável a uns e irrefletido para outros.

Essa atuação irrefletida se estabelece, também, nos usos da linguagem por parte dos atores sociais, que, socializados dentro de certas práticas linguísticas, tenderão a reproduzi-las. O domínio de uma forma de comunicação ultrapassa o mero conhecimento dos signos. Requer o entendimento adequado de seus usos em contexto, para que de fato a comunicação, mais do que entendida, seja aceita. Essa discussão é pertinente por permitir que se pense sobre os modos de inserção dos pesquisadores no mundo, tendo em vista que não lhes bastará dominar uma língua e que serão instados a incorporar outras formas de agir que poderão influenciar suas práticas de pesquisa e sua relação com o ambiente acadêmico no qual se insere.

\footnotetext{
${ }^{1}$ Doutor em Administração pela UFMG. Professor da Fundação Getulio Vargas. E-mail: amon.barros@fgv.br
} 


\section{À GUISA DE CONCLUSÃO: O HABITUS DE PESQUISADORES E PESQUISADORAS INSERIDOS NO MUNDO \\ Amon Narciso de Barros}

Em um dado ponto do debate, é apresentada a ideia de que a pesquisa é uma espécie de artesanato. Nesse sentido, e usando essa indicação como uma metáfora, é possível entender a importância da prática de pesquisa para o seu aprimoramento. Ao mesmo tempo, a formação de novos pesquisadores deve se dar de modo a permitir o aprendizado supervisionado na prática. Contudo, nota-se que, muitas vezes, o que temos são pesquisadores mais experientes se distanciando paulatinamente da pesquisa em virtude de múltiplas demandas que recaem sobre eles, desde as tarefas cotidianas ligadas à atividade docente até a demanda por cumprir métricas que lhes são cobradas e colocadas. Assim, os orientadores passam da tarefa de tutoria à função de gestão. Isso, por vezes, os impede de exercer a pesquisa e acompanhar a prática dos novos entrantes sob sua responsabilidade.

Ao mesmo tempo, esse distanciamento da prática leva o pesquisador a se tornar outra coisa e incorporar outras lógicas ao seu comportamento. Nesse sentido, o habitus passa a ser formado a partir de um ethos muito mais voltado para a razão utilitária do que para as dimensões substantivas da produção do conhecimento, incluindo aí as políticas. Observa-se que, desse modo, a pesquisa tende a ficar ainda mais engessada em suas formas aceitas de antemão. Fica pouco espaço para a inovação, para o risco e para o trabalho que requeira o vagar para se desenvolver, como costuma ser o caso com atividades reflexivas.

Neste sentido, o debate proposto pelos autores abre espaço para que a academia repense alguns rumos que talvez tenham sido tomados sem que se pensasse de fato em seus efeitos. A Sociedade Brasileira de Estudos Organizacionais, que recebeu esta discussão em sala cheia no seu quarto encontro anual, não poderia ser espaço mais propício para ensejar tais debates. Como se sabe, a associação foi originada no desejo de romper com algumas amarras que limitavam o desenvolvimento dos debates no campo. Ela, ainda, se propõe a ser um espaço de formação inclusivo, que recebe igualmente pesquisadores em qualquer momento de sua formação. Nesse sentido, o chamado para considerar o habitus como uma dimensão essencial, mas ignorada, da formação do pesquisador deve ser recebido com atenção. Ao mesmo tempo, não se pode achar que a inserção do pesquisador na sua polis, bem como os efeitos imediatos e no tempo de suas práticas sejam assuntos já resolvidos. A realidade impõe constantes desafios e não se pode subestimar a necessidade de nos conduzirmos de modo a produzir conteúdos e sentidos não apenas para si ou para órgãos burocráticos, mas também e especialmente para o mundo que nos abriga.

Submetido em: $24 / 03 / 2017$

Aprovado em: 20/04/2017

Revista Brasileira de Estudos Organizacionais - v. 3. n. 2, p. 216-217, dez.2016, eISSN: 2447-4851 Doi 10.21583/2447-4851.rbeo.2016.v3n2.85

Sociedade Brasileira de Estudos Organizacionais 